\author{
Marquette University \\ e-Publications@Marquette
}

School of Dentistry Faculty Research and

Publications

Dentistry, School of

$1-2016$

\title{
Clinical Practice Guidelines for Recall and Maintenance of Patients with Tooth-Borne and Implant-Borne Dental Restorations
}

\author{
Avinash S. Bidra \\ University of Connecticut Health Center \\ Diane M. Daubert \\ University of Washington School of Dentistry \\ Lily T. Garcia \\ University of lowa College of Dentistry \& Dental Clinics \\ Timothy F. Kosinski \\ University of Detroit Mercy School of Dentistry \\ Conrad A. Nenn \\ Marquette University, conrad.nenn@marquette.edu
}

See next page for additional authors

Follow this and additional works at: https://epublications.marquette.edu/dentistry_fac

Part of the Dentistry Commons

\section{Recommended Citation}

Bidra, Avinash S.; Daubert, Diane M.; Garcia, Lily T.; Kosinski, Timothy F.; Nenn, Conrad A.; Olsen, John A.; Platt, Jeffrey A.; Wingrove, Susan S.; Chandler, Nancy Deal; and Curtis, Donald A., "Clinical Practice Guidelines for Recall and Maintenance of Patients with Tooth-Borne and Implant-Borne Dental Restorations" (2016). School of Dentistry Faculty Research and Publications. 136.

https://epublications.marquette.edu/dentistry_fac/136 
Authors

Avinash S. Bidra, Diane M. Daubert, Lily T. Garcia, Timothy F. Kosinski, Conrad A. Nenn, John A. Olsen, Jeffrey A. Platt, Susan S. Wingrove, Nancy Deal Chandler, and Donald A. Curtis

This article is available at e-Publications@Marquette: https://epublications.marquette.edu/dentistry_fac/136 


\title{
Clinical Practice Guidelines for Recall and Maintenance of Patients with Tooth-Borne and Implant- Borne Dental Restorations
}

\author{
Avinash S. Bidra \\ Department of Reconstructive Sciences, \\ University of Connecticut Health Center, \\ Farmington, CT \\ Diane M. Daubert \\ Department of Periodontics, \\ University of Washington School of Dentistry, \\ Seattle, WA \\ Lily T. Garcia \\ Office of the Dean, \\ University of Iowa College of Dentistry \& Dental Clinics, \\ Iowa City, IA \\ Timothy F. Kosinski \\ Department of Restorative Dentistry, \\ University of Detroit Mercy School of Dentistry, \\ Detroit, $M I$
}


NOT THE PUBLISHED VERSION; this is the author's final, peer-reviewed manuscript. The published version may be accessed by following the link in the citation at the bottom of the page.

\author{
Conrad A. Nenn \\ Department of General Dental Sciences, School of Dentistry, \\ Marquette University \\ Milwaukee, WI \\ John A. Olsen \\ Private Practice, \\ Franklin, WI \\ Jeffrey A. Platt \\ Department of Biomedical and Applied Sciences, Division of \\ Dental Biomaterials, Indiana University School of Dentistry, \\ Indianapolis, IN \\ Susan S. Wingrove \\ Private Practice Hygienist, Regeneration Research, \\ Missoula, MT \\ Nancy Deal Chandler \\ Executive Director, American College of Prosthodontists and ACP \\ Education Foundation, \\ Chicago, IL \\ Donald A. Curtis \\ Department of Preventive \& Restorative Dental Sciences, \\ UCSF School of Dentistry, \\ San Francisco, CA
}

\begin{abstract}
Purpose: To provide guidelines for patient recall regimen, professional maintenance regimen, and at-home maintenance regimen for patients with tooth-borne and implant-borne removable and fixed restorations.

Materials and Methods: The American College of Prosthodontists (ACP) convened a scientific panel of experts appointed by the ACP, American Dental Association (ADA), Academy of General Dentistry (AGD), and American Dental Hygienists Association (ADHA) who critically evaluated and debated recently published findings from two systematic reviews on this topic. The major outcomes and consequences considered during formulation of the clinical practice guidelines (CPGs) were risk for failure of tooth- and implant-borne restorations. The panel conducted a round table discussion of the proposed
\end{abstract}


guidelines, which were debated in detail. Feedback was used to supplement and refine the proposed guidelines, and consensus was attained.

Results: A set of CPGs was developed for tooth-borne restorations and implant-borne restorations. Each CPG comprised (1) patient recall, (2) professional maintenance, and (3) at-home maintenance. For tooth-borne restorations, the professional maintenance and at-home maintenance CPGs were subdivided for removable and fixed restorations. For implant-borne restorations, the professional maintenance CPGs were subdivided for removable and fixed restorations and further divided into biological maintenance and mechanical maintenance for each type of restoration. The at-home maintenance CPGs were subdivided for removable and fixed restorations.

Conclusions: The clinical practice guidelines presented in this document were initially developed using the two systematic reviews. Additional guidelines were developed using expert opinion and consensus, which included discussion of the best clinical practices, clinical feasibility, and riskbenefit ratio to the patient. To the authors' knowledge, these are the first CPGs addressing patient recall regimen, professional maintenance regimen, and at-home maintenance regimen for patients with tooth-borne and implantborne restorations. This document serves as a baseline with the expectation of future modifications when additional evidence becomes available.

Clinical practice guidelines (CPG) are intended to provide clinicians with guidance in diagnosis, treatment planning, and clinical decision-making. ${ }^{1}$ CPGs have been shown to improve patient care processes and clinical outcomes, and to better identify and limit treatment risks. ${ }^{1-4}$ Although empirically developed CPGs have been used in medicine for hundreds of years, in the 1990s systematic approaches were advanced and advocated for CPGs. In an extensive systematic review of 59 published CPGs in medicine, Grimshaw and Russell ${ }^{4}$ showed that explicit CPGs improved clinical practice when introduced in the context of rigorous evaluations. In dentistry, a few oft-cited CPGs include the use of antibiotic prophylaxis before dental procedures to prevent endocarditis in certain cardiac patients, ${ }^{5}$ the use of prophylactic antibiotics prior to dental procedures in patients with prosthetic joints, ${ }^{6}$ antibiotic prophylaxis for dental patients at risk for infection, ${ }^{7}$ oral health care for the pregnant adolescent, ${ }^{8}$ guidelines for the care and maintenance of complete dentures, ${ }^{9}$ management of patients with medication-related osteonecrosis of the jaws (MRONJ) ${ }^{10}$ and many others. ${ }^{11}$ The United States maintains a national registry in the National Guideline Clearinghouse for evidence-based clinical practice guidelines, which are submitted and endorsed by various medical and professional organizations. ${ }^{11}$ It is important to note that unlike traditional CPGs based on empiricism or medical authority, 
modern CPGs involve a systematic and transparent process for scrutiny of scientific evidence, and recommendations are made with the intent that they will be updated and modified as scientific evidence becomes available. ${ }^{1-4}$ Despite this, recommendations made in CPGs are not always supported by scientific evidence. This is because many empirical procedures and treatments that yield favorable outcomes do not necessarily have scientific evidence at the present time. ${ }^{12}$

Patients seeking prosthodontic care often present with significant previous dental treatment, a complex etiology of factors contributing to the loss of teeth, loss of tooth structure, and equally complex treatment needs to restore function and esthetics. Treatment plans to address patient needs using tooth- or implant-borne restorations require careful diagnosis, risk assessment, treatment planning, meticulous execution of care, and a long-term partnership with the patient and treatment team to maintain an enduring result. Given the resources required to treat patients with complex dental needs, an appropriate patient recall regimen, professional maintenance regimen, and at-home maintenance regimen are paramount for long-term success. ${ }^{13,14}$ Furthermore, it is likely that the professional and at-home maintenance protocols in healthy adult patients with tooth- and implant-borne restorations may be significantly different when compared to patients with no restorations, or patients with acute or chronic oral and systemic diseases. For toothborne restorations, guidelines on the options and relative merits of professional and at-home maintenance protocols to predictably achieve stable results are lacking. ${ }^{13}$ Current guidelines for the maintenance of implant restorations are poorly defined and often based on empiricism or traditional protocols for patients with natural dentition rather than what is most suitable for maintenance of implant restorations and supporting tissues. ${ }^{14}$ Therefore, professional and athome maintenance guidelines are necessary for patients with toothand implant-borne removable and fixed restorations to improve the health of supporting tissues, limit disease processes such as caries, periodontitis, or peri-implant disease, and improve the expected longevity of restorations as well as the supporting teeth and implants themselves. Guidelines are needed to provide direction for the dental health care provider with the goal of improved clinical outcomes for the patient.

Journal of Prosthodontics, Vol 25, No. S1 (January 2016): pg. 532-540. DOI. This article is (C) Wiley and permission has been granted for this version to appear in e-Publications@Marquette. Wiley does not grant permission for this article to be further copied/distributed or hosted elsewhere without the express permission from Wiley. 
NOT THE PUBLISHED VERSION; this is the author's final, peer-reviewed manuscript. The published version may be accessed by following the link in the citation at the bottom of the page.

\section{Purpose}

Patients with complex tooth- and implant-borne restorations require a lifelong professional recall regimen to provide biological and mechanical maintenance customized for each patient. Therefore, the purpose of this CPG document is to provide: (1) guidelines for patient recall regimen, professional maintenance regimen, and at-home maintenance regimen for patients with tooth-borne restorations and (2) guidelines for patient recall regimen, professional maintenance regimen, and at-home maintenance regimen for patients with implantborne restorations. The target populations of this CPG are patients with tooth- and implant-borne removable and fixed restorations. The intended users of the presented CPGs are: general dentists, dental hygienists, prosthodontists and other dental specialists, dental health care providers, allied health personnel, nurses, social workers, students, patients, medical and dental insurance carriers, and public health departments.

\section{Methods}

To the authors' knowledge, this is the first CPG addressing patient recall regimen, professional maintenance regimen, and athome maintenance regimen for patients with tooth- and implant-borne restorations and serves as a baseline for future modifications and versions based on future scientific evidence. Two separate systematic reviews of the literature were conducted to evaluate the recall and maintenance regimens for tooth- and implant-borne restorations. ${ }^{13,14}$ The systematic review on tooth-borne restorations included articles published from January 1, 1999 to December 31, 2014. The systematic review on implant-borne restorations included articles published from January 1, 2004 to December 31, 2014. The detailed methodology for the search processes are described in the respective systematic review articles. ${ }^{13,14}$ For tooth-borne restorations, 16 studies were identified in the systematic review that reported data on a combined 3569 patients. Of these, nine were randomized controlled clinical trials (RCT), and seven were observational studies. For implant-borne restorations, 20 studies were identified, reporting on 1088 patients. Of these, eleven were RCTs, and nine were observational studies. Results from all of these studies were 
scrutinized, tabulated, and analyzed to formulate conclusions and then create the CPGs

A scientific panel comprising experts appointed by the American College of Prosthodontists (ACP), American Dental Association (ADA), Academy of General Dentistry (AGD), and American Dental Hygienists Association (ADHA) critically evaluated and debated the published evidence from two systematic reviews on this topic. A rating scheme for strength of recommendation as described by Shekelle et al ${ }^{1}$ was used as it was most applicable to this topic and is widely used and validated in the medical literature (Tables 1 and 2). The major outcomes and consequences considered during formulation of these CPGs were (1) risk for failure of tooth-borne restorations and (2) risk for failure of implant-borne restorations. Thereafter, the members of the task force conducted a roundtable peer review/evaluation discussion of the proposed guidelines, and the guidelines were debated in detail. These inputs were used to supplement and refine the proposed guidelines, and consensus was attained for the various guidelines presented.

Table 1. Levels and category of evidence as described by Shekelle et al ${ }^{1}$

\begin{tabular}{ll} 
Level & \multicolumn{1}{c}{ Category of evidence } \\
Ia & Evidence from systematic review of randomized controlled trials \\
Ib & Evidence from at least one randomized controlled trial \\
IIa & Evidence from at least one controlled study without randomization \\
IIb & $\begin{array}{l}\text { Evidence from at least one other type of quasi-experimental study, such as } \\
\text { time series analysis or studies in which the unit of analysis is not the individual }\end{array}$ \\
III & $\begin{array}{l}\text { Evidence from non-experimental descriptive studies, such as comparative } \\
\text { studies, correlation studies, cohort studies, and case-control studies }\end{array}$ \\
IV & $\begin{array}{l}\text { Evidence from expert committee reports or opinions or clinical experience of } \\
\text { respected authorities or both }\end{array}$
\end{tabular}

Table 2. Rating scheme for the strength of recommendation as described by Shekelle et al $^{1}$

\begin{tabular}{ll} 
Classification & \multicolumn{1}{c}{$\begin{array}{c}\text { Strength of recommendation } \\
\text { A }\end{array}$} \\
\hline B & $\begin{array}{l}\text { Directly based on category I evidence } \\
\text { I evidence }\end{array}$ \\
\hline C & $\begin{array}{l}\text { Directly based on category III evidence or extrapolated from category } \\
\text { I or II evidence }\end{array}$ \\
D & Directly based on category IV evidence or extrapolated from category \\
& I, II, or III evidence
\end{tabular}

Journal of Prosthodontics, Vol 25, No. S1 (January 2016): pg. 532-540. DOI. This article is (C Wiley and permission has been granted for this version to appear in e-Publications@Marquette. Wiley does not grant permission for this article to be further copied/distributed or hosted elsewhere without the express permission from Wiley. 
NOT THE PUBLISHED VERSION; this is the author's final, peer-reviewed manuscript. The published version may be accessed by following the link in the citation at the bottom of the page.

\section{Results}

Patients with tooth- and implant-borne restorations require a lifelong professional recall regimen to provide biological and mechanical maintenance, customized for each patient. Therefore, a set of CPGs was created for each type of restoration comprising (1) patient recall, (2) professional maintenance, and (3) at-home maintenance. The CPGs are presented in Table 3 for tooth-borne restorations ${ }^{15-30}$ and Table 4 for implant-borne restorations. ${ }^{31-50}$ For tooth-borne restorations, the professional maintenance and at-home maintenance CPGs were subdivided for removable and fixed restorations. For implant-borne restorations, the professional maintenance CPGs were sub-divided for removable and fixed restorations and further divided into biological maintenance and mechanical maintenance for each type of restoration. The at-home maintenance CPGs were subdivided for removable and fixed restorations. The strength of evidence and subsequent recommendations that is presently available was applied for each guideline. When a guideline comprised multiple aspects, multiple strengths of recommendations in descending order were applied. Additionally, when multiple strengths of recommendation were available for a specific guideline, they were all applied accordingly.

Table 3. Clinical practice guidelines for recall and maintenance of patients with tooth-borne dental restorations

\begin{tabular}{|l|l|l|c|}
\hline Number & Topic & Guideline & Strength of \\
\hline
\end{tabular}

1. Guidelines $2 A, 2 B, 3 A$, and $3 B$ are supported by references 15 through 30 .

1.

\section{Patient recall}

\author{
Patients with tooth-borne \\ restorations (fixed or \\ removable) should be advised \\ to obtain a dental professional \\ examination at least every 6 \\ months as a lifelong regimen. \\ Patients categorized by the \\ dentist as higher risk based on \\ age, ability to perform oral \\ self care, biological or \\ mechanical complications of \\ natural teeth or tooth-borne \\ restorations should be advised \\ to obtain a dental professional \\ examination more often than \\ every 6 months, depending \\ upon the clinical situation.
}

D

D

Journal of Prosthodontics, Vol 25, No. S1 (January 2016): pg. 532-540. DOI. This article is @ Wiley and permission has been granted for this version to appear in e-Publications@Marquette. Wiley does not grant permission for this article to be further copied/distributed or hosted elsewhere without the express permission from Wiley. 
NOT THE PUBLISHED VERSION; this is the author's final, peer-reviewed manuscript. The published version may be accessed by following the link in the citation at the bottom of the page.

\begin{tabular}{l|l} 
Number & \multicolumn{1}{c}{ Topic } \\
\hline $2 \mathrm{~A}$. & - $\begin{array}{l}\text { Professional } \\
\text { maintenance: }\end{array}$ \\
& - $\begin{array}{l}\text { Tooth-borne } \\
\text { removable } \\
\text { restorations (partial } \\
\text { removable dental } \\
\text { prostheses) }\end{array}$ \\
&
\end{tabular}

2B.

\section{- Professional} maintenance:

- Tooth-borne fixed restorations (intracoronal restorations, extracoronal restorations, veneers, single crowns, and partial fixed dental prostheses) th and intervention, oral hygiene natural teeth and restorations), and use of oral topical agents as deemed clinically necessary.

Professional maintenance of the partial removable dental prostheses should include hygiene instructions, detailed examination of the prosthesis, prosthetic components and patient education about any foreseeable problems that could impair optimal function with the restoration. The partial removable dental prosthesis should be professionally cleaned extraorally using professionally accepted mechanical and chemical methods.

Professionals should recommend and/or prescribe appropriate oral topical agents and oral hygiene aids suitable for the patient's at-home maintenance needs.

Professional maintenance for patients with tooth-borne fixed restorations should include an extraoral and intraoral health and dental examination, oral hygiene instructions for natural teeth and the fixed restorations, oral hygiene intervention (cleaning of natural teeth and restorations), and use of oral topical agents as deemed clinically necessary.

Professionals should recommend and/or prescribe appropriate oral topical agents and oral hygiene aids suitable for the patient's at-home maintenance needs.

When clinical signs indicate the need for an occlusal

\section{Strength of} recommendation

A, C, D

D

D

A, C, D

Journal of Prosthodontics, Vol 25, No. S1 (January 2016): pg. 532-540. DOI. This article is (C Wiley and permission has been granted for this version to appear in e-Publications@Marquette. Wiley does not grant permission for this article to be further copied/distributed or hosted elsewhere without the express permission from Wiley. 
NOT THE PUBLISHED VERSION; this is the author's final, peer-reviewed manuscript. The published version may be accessed by following the link in the citation at the bottom of the page.

Number $\quad$ Topic

$3 A$.

- At-home
maintenance:
Tooth-borne
removable
restorations (partial
removable dental
prostheses)

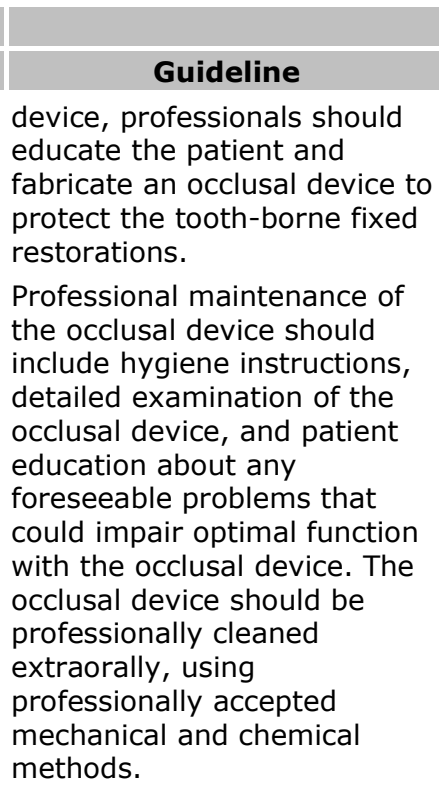

Professional maintenance of the occlusal device should include hygiene instructions, detailed examination of the occlusal device, and patient education about any foreseeable problems that could impair optimal function with the occlusal device. The occlusal device should be professionally cleaned extraorally, using professionally accepted mechanical and chemical methods.

Patients with tooth-borne removable restorations should be educated about brushing existing natural teeth and restorations twice daily, and the use of oral hygiene aids such as dental floss, water flossers, air flossers, interdental cleaners, and electric toothbrushes.

Patients with tooth-borne removable restorations should be educated about cleaning their prosthesis at least twice daily using a soft brush and the professional recommended denture-cleaning agent.

Patients with multiple and complex restorations on existing teeth supporting or surrounding the removable restoration should be advised to use oral topical agents such as toothpaste containing 5000 ppm fluoride or toothpaste with $0.3 \%$ triclosan, and to add supplemental short-term use of chlorhexidine gluconate when indicated.

Patients with tooth-borne removable restorations should be advised to remove the restoration while sleeping. The removed prosthesis should be stored in a prescribed cleaning solution.
Strength of recommendation

D

C, D

D

A, C, D

D

Journal of Prosthodontics, Vol 25, No. S1 (January 2016): pg. 532-540. DOI. This article is (C) Wiley and permission has been granted for this version to appear in e-Publications@Marquette. Wiley does not grant permission for this article to be further copied/distributed or hosted elsewhere without the express permission from Wiley. 
NOT THE PUBLISHED VERSION; this is the author's final, peer-reviewed manuscript. The published version may be accessed by following the link in the citation at the bottom of the page.

\begin{tabular}{ll}
\hline Number & \multicolumn{1}{c}{ Topic } \\
\hline 3B. & $\begin{array}{l}\text { At-home } \\
\text { maintenance: } \\
\text { Tooth-borne fixed } \\
\text { restorations } \\
\text { (intracoronal } \\
\text { restorations, } \\
\text { extracoronal } \\
\text { restorations, veneers, } \\
\text { single crowns, and } \\
\text { partial fixed dental } \\
\text { prostheses) }\end{array}$ \\
\end{tabular}

Guideline

Patients with tooth-borne

fixed restorations should be educated about brushing twice daily and the use of oral hygiene aids such as dental floss, water flossers, air flossers, interdental cleaners, and electric toothbrushes.

\section{Strength of recommendation \\ A, D}

Patients with multiple and
complex restorations on
existing teeth should be
advised to use oral topical
agents such as toothpaste
containing 5000 ppm fluoride
or toothpaste with $0.3 \%$
triclosan, and to add
supplemental short-term use
of chlorhexidine gluconate
when indicated.
Patients prescribed with
occlusal devices should be
educated to wear the occlusal
device during sleep.
Patients prescribed with
occlusal devices should be
educated about cleaning their
occlusal device before and
after use, with a soft brush
and the prescribed cleaning
agent. Patients should also be
educated about proper
methods for storage of the
occlusal device when not in
use.

Table 4. Clinical practice guidelines for recall and maintenance of patients with implant-borne dental restorations

\begin{tabular}{|c|c|c|c|}
\hline & & & Strength of \\
\hline Number & Topic & Guideline & recommendation \\
\hline
\end{tabular}

1. Guidelines 2A, 2B, 2C, 2D, 3A, and 3B are supported by references 31 through 50 .

1. Patient recall
Patients with implant-borne restorations (fixed or removable) should be advised to obtain a dental professional examination visit at least every 6 months as a lifelong regimen.

Patients categorized by the dentist as higher risk based on age, ability to perform oral self 
NOT THE PUBLISHED VERSION; this is the author's final, peer-reviewed manuscript. The published version may be accessed by following the link in the citation at the bottom of the page.

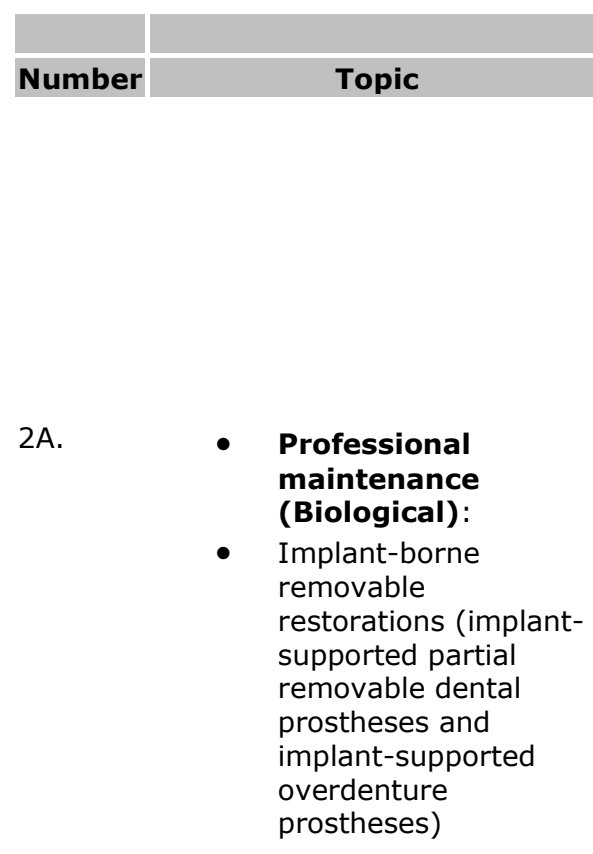

\begin{tabular}{l}
\multicolumn{1}{c}{ Guideline } \\
care, biological or mechanical \\
complications of remaining \\
natural teeth, tooth-borne \\
restorations or implant-borne \\
restorations should be advised to \\
obtain a dental professional \\
examination more often than \\
every 6 months, depending upon \\
the clinical situation.
\end{tabular}

Professional biological

maintenance for patients with

implant-borne removable

restorations should include an extraoral and intraoral health and

dental examination, oral hygiene

instructions, hygiene instructions for the prostheses and oral hygiene intervention (cleaning of any natural teeth, tooth-borne restorations, implant-borne restorations, or implant abutments).

Professionals should use chlorhexidine gluconate as the oral topical agent of choice when antimicrobial effect is needed clinically.

Professionals should use cleaning instruments compatible with the type and material of the implants, abutments and restorations, and powered instruments such as the glycine powder air polishing system.

Implant-supported partial removable dental prostheses and implant-supported overdenture prostheses should be professionally cleaned extraorally using professionally accepted mechanical and chemical cleaning methods.

Professionals should recommend and/or prescribe appropriate oral topical agents and oral hygiene aids suitable for the patient's athome maintenance needs.

Professional mechanical maintenance for patients with implant-borne removable restorations should include a detailed examination of the prosthesis, intra and extraoral prosthetic components, and patient education of foreseeable problems that could impair

with

Strength of recommendation

A, C, D

A, C

A, C, D

D

$A, C, D$

C, D

\section{maintenance}

(Mechanical):

- Implant-borne removable restorations (implantsupported partial removable dental prostheses and 
NOT THE PUBLISHED VERSION; this is the author's final, peer-reviewed manuscript. The published version may be accessed by following the link in the citation at the bottom of the page.

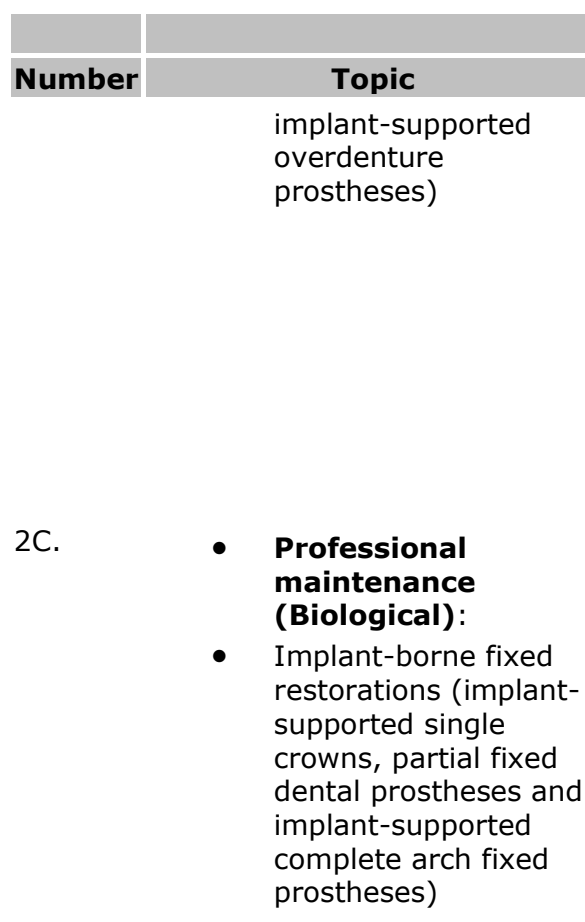

2D.
- Professional
maintenance (Mechanical):

Professionals should recommend and perform adjustment, repair, replacement, or remake of any or all parts of the prosthesis and prosthetic components that could compromise function.

Professional biological maintenance for patients with implant-borne fixed restorations should include an extraoral and intraoral health and dental examination, oral hygiene instructions, and oral hygiene intervention (cleaning of any natural teeth, tooth-borne restorations, implant-borne restorations, or implant abutments).

Professionals should use chlorhexidine gluconate as the oral topical agent of choice when antimicrobial effect is needed clinically.

Professionals should use cleaning instruments compatible with the type and material of the implants, abutments, and restorations, and powered instruments such as the glycine powder air polishing system.

In patients with implantsupported fixed prostheses, the decision to remove the prosthesis for biological maintenance should be based on the patient's demonstrated inability to perform adequate oral hygiene. The prosthesis contours should be reassessed to facilitate at-home maintenance.

Professionals should consider using new prosthetic screws when an implant-borne restoration is removed and replaced for professional biological maintenance.

Professional mechanical maintenance for patients with implant-borne fixed restorations should include a detailed examination of the prosthesis,
C, D

$A, C, D$

A, C

A, C, D

D

D

C, D

Journal of Prosthodontics, Vol 25, No. S1 (January 2016): pg. 532-540. DOI. This article is (C Wiley and permission has been granted for this version to appear in e-Publications@Marquette. Wiley does not grant permission for this article to be further copied/distributed or hosted elsewhere without the express permission from Wiley. 
NOT THE PUBLISHED VERSION; this is the author's final, peer-reviewed manuscript. The published version may be accessed by following the link in the citation at the bottom of the page.

\begin{tabular}{ll} 
Number & \multicolumn{1}{c}{ Topic } \\
\hline - & $\begin{array}{l}\text { Implant-borne fixed } \\
\text { restorations (implant- } \\
\text { supported single } \\
\text { crowns, partial fixed } \\
\text { dental prostheses, and } \\
\text { implant-supported } \\
\text { complete arch fixed } \\
\text { prostheses) }\end{array}$ \\
\end{tabular}

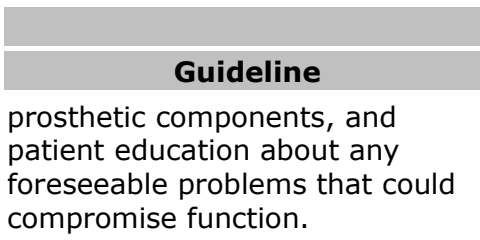

prosthetic components, and patient education about any foreseeable problems that could compromise function.

crown partial fixed prostheses)

$3 A$. maintenance:

Professionals should recommend and perform adjustment, repair, replacement, or remake of any or all parts of the prosthesis and prosthetic components that could impair patient's optimal function.

Professionals should consider using new prosthetic screws when an implant-borne restoration is removed and replaced for professional mechanical maintenance.

When clinical signs indicate the need for an occlusal device, professionals should educate the patient and fabricate an occlusal device to protect implant-borne fixed restorations.

Professional maintenance of the occlusal device should include hygiene instructions, detailed examination of the occlusal device, and patient education about any foreseeable problems that could impair optimal function with the occlusal device. The occlusal device should be professionally cleaned extraorally using professionally accepted mechanical and chemical methods.

Patients with multiple and complex restorations on existing teeth should be advised to use oral topical agents such as toothpaste containing 5000 ppm fluoride or toothpaste with $0.3 \%$ triclosan, and to add supplemental short-term use of chlorhexidine gluconate when indicated.

Patients prescribed with occlusal devices should be educated to wear the occlusal device during sleep.

Patients with implant-supported partial removable dental prostheses should be educated
C, D

D

D

D

$A, C, D$

D

C, D

Journal of Prosthodontics, Vol 25, No. S1 (January 2016): pg. 532-540. DOI. This article is @ Wiley and permission has been granted for this version to appear in e-Publications@Marquette. Wiley does not grant permission for this article to be further copied/distributed or hosted elsewhere without the express permission from Wiley. 
NOT THE PUBLISHED VERSION; this is the author's final, peer-reviewed manuscript. The published version may be accessed by following the link in the citation at the bottom of the page.

\begin{tabular}{|c|c|}
\hline Number & Topic \\
\hline & $\begin{array}{l}\text { - Implant-borne } \\
\text { removable } \\
\text { restorations (implant- } \\
\text { supported partial } \\
\text { removable dental } \\
\text { prostheses, and } \\
\text { implant-supported } \\
\text { overdenture } \\
\text { prostheses) }\end{array}$ \\
\hline
\end{tabular}

Guideline

about brushing existing natural teeth and restorations twice daily, and the use of oral hygiene aids such as dental floss, water flossers, air flossers, interdental cleaners, and electric toothbrushes.
Strength of recommendation

\begin{abstract}
Patients with implant-borne removable restorations should be advised to clean their intraoral implant components at least twice daily, using a soft brush and the professionally recommended oral topical agent.
\end{abstract}

Patients with implant-borne removable restorations should be advised to clean their prosthesis at least twice daily using a soft brush with a professional recommended denture-cleaning agent.

Patients with implant-borne partial or complete removable restorations should be advised to remove the restoration while sleeping. The removed prosthesis should be stored in a prescribed cleaning solution.

3B.

\section{- At-home} maintenance:

- Implant-borne fixed restorations (implantsupported single crowns, partial fixed dental prostheses and implant-supported complete arch fixed prostheses)
Patients with implant-borne fixed restorations should be educated about brushing twice daily and the use of oral hygiene aids such as dental floss, water flossers, air flossers, interdental cleaners and electric toothbrushes.
Patients with multiple and complex implant-borne fixed restorations, should be advised to use oral topical agents such as toothpaste containing $0.3 \%$ triclosan and to add supplemental short-term use of chlorhexidine gluconate when indicated.

Patients prescribed with occlusal devices should be educated to wear the occlusal device during sleep.

Patients prescribed with occlusal devices should be educated about
D

D

D

C, D

A, C, D

D

D

Journal of Prosthodontics, Vol 25, No. S1 (January 2016): pg. 532-540. DOI. This article is (C) Wiley and permission has been granted for this version to appear in e-Publications@Marquette. Wiley does not grant permission for this article to be further copied/distributed or hosted elsewhere without the express permission from Wiley. 
NOT THE PUBLISHED VERSION; this is the author's final, peer-reviewed manuscript. The published version may be accessed by following the link in the citation at the bottom of the page.

\begin{tabular}{|c|c|c|c|}
\hline & & & Strength of \\
\hline \multirow[t]{2}{*}{ Number } & Topic & Guideline & recommendation \\
\hline & & $\begin{array}{l}\text { cleaning their occlusal device } \\
\text { before and after use, with a soft } \\
\text { brush and the prescribed cleaning } \\
\text { agent. Patients should also be } \\
\text { educated about proper methods } \\
\text { for storage of the occlusal device } \\
\text { when not in use. }\end{array}$ & \\
\hline
\end{tabular}

\section{Discussion}

The scientific panel considered the potential benefits, harms, contraindications, and scope of these guidelines. The potential benefits for these guidelines include (1) improved oral health and longevity of natural teeth, tooth-borne, and implant-borne restorations and (2) improved oral health related quality of life. The potential harms considered were (1) increased short-term cost to patients to adhere to recall regimen, professional maintenance regimen, and at-home maintenance regimen and (2) adverse effects related to any of the professionally used oral topical agents or at-home oral topical agents and oral hygiene aids. The contraindications to these guidelines include allergies or adverse effects related to any of the professionally used oral topical agents or at-home oral topical agents.

A potential source of bias that was considered during development of the CPGs was the same group serving as authors of the systematic reviews as well as panel members for the CPG. ${ }^{51,52}$ To minimize this potential bias, efforts were made during the scientific panel meetings to debate and justify each guideline in an open and transparent format. Financial and organizational conflicts of interests were not identified. Strength of evidence was debated for every guideline. Thus, the effect of "groupthink" may not be a source of bias in this baseline CPG document. Conversely, having the same author group to draft the CPGs may be viewed as a strength of this document, due to the profound insight obtained by the author group during the systematic review process.

Most of the guidelines in this document are graded as category $\mathrm{D}$ for strength of recommendation, but it is anticipated that the strength of recommendation would be higher in the future. Using Shekelle's method ${ }^{1}$ for grading the strength of recommendation

Journal of Prosthodontics, Vol 25, No. S1 (January 2016): pg. 532-540. DOI. This article is (C) Wiley and permission has been granted for this version to appear in e-Publications@Marquette. Wiley does not grant permission for this article to be further copied/distributed or hosted elsewhere without the express permission from Wiley. 
allowed incorporation and delineation of various types of evidence, including expert opinion/consensus, into four categories, while formulating these guidelines. Additionally, it allowed extrapolation of higher categories of evidence to lower categories and provided more freedom in designation of an article to a specific category. The authors considered other widely popular alternatives such as Grading of Recommendations Assessment, Development and Evaluation (GRADE) method, ${ }^{53}$ and the Strength of Recommendation Taxonomy (SORT) method. ${ }^{54}$ However, these alternatives were less applicable to the topic of this baseline CPG. The GRADE method divides the expression of evidence into only two categories, weak or strong, which was not appropriate for this baseline CPG. The SORT method divides the strength of recommendation into three categories ( $A, B$ and $C$ ) but does not allow extrapolation of higher categories of evidence to lower categories. ${ }^{54}$

This document is intended for healthy adult patients with toothor implant-borne restorations. Management of patients with mixed restorations (tooth- and implant-borne removable or fixed restorations) in one or both jaws should encompass both sets of proposed guidelines, appropriate to the clinical situation. Management of patients with conditions such as bruxism, xerostomia, periodontal disease, peri-implant disease, or other conditions are outside the scope of these CPGs; however, the recall and maintenance regimen guidelines made in this document would likely be helpful to these patients. This baseline document is intended to improve patient care protocols, but is not intended as a standard of care. The outlined CPGs should be supplemented with professional judgment and consideration of the unique needs and preferences of each patient.

\section{Summary}

This document provides clinical practice guidelines for patient recall regimen, professional maintenance regimen, and at-home maintenance regimen for patients with tooth-borne and implant-borne restorations. The various guidelines were made using the best level of evidence whenever available. Guidelines made using expert opinion and consensus included the best possible analysis of best clinical practices, clinical feasibility, and risk-benefit ratio for patients. A 
scientific panel appointed by the American College of Prosthodontists $(A C P)$, American Dental Association (ADA), Academy of General Dentistry (AGD), and American Dental Hygienists Association (ADHA) developed and approved the CPGs. This document serves as a baseline with the expectation of future modifications to reflect best clinical practices and when additional evidence becomes available.

\section{References}

${ }^{1}$ Shekelle PG, Woolf SH, Eccles M, et al: Clinical guidelines: developing guidelines. Brit Med J 1999;318:593-596

${ }^{2}$ Fervers B, Burgers JS, Haugh MC, et al: Predictors of high quality clinical practice guidelines: examples in oncology. Int J Qual Health Care 2005; 17:123-132

${ }^{3}$ Burgers JS, Grol R, Klazinga NS, et al, for the AGREE Collaboration: Towards evidence-based clinical practice: an international survey of 18 clinical guideline programs. Int J Qual Health Care 2003;15:31-45

${ }^{4}$ Grimshaw JM, Russell IT: Effect of clinical guidelines on medical practice: a systematic review of rigorous evaluations. Lancet 1993;342:13171322

${ }^{5}$ Wilson W, Taubert KA, Gewitz M, et al: Prevention of infective endocarditis: guidelines from the American Heart Association: a guideline from the American Heart Association Rheumatic Fever, Endocarditis and Kawasaki Disease Committee, Council on Cardiovascular Disease in the Young, and the Council on Clinical Cardiology, Council on Cardiovascular Surgery and Anesthesia, and the Quality of Care and Outcomes Research Interdisciplinary Working Group. J Am Dent Assoc 2008;139 Suppl:3S-24S

${ }^{6}$ Sollecito TP, Abt E, Lockhart PB, et al: The use of prophylactic antibiotics prior to dental procedures in patients with prosthetic joints: evidencebased clinical practice guideline for dental practitioners-a report of the American Dental Association Council on Scientific Affairs. J Am Dent Assoc 2015;146:11-16.e8

${ }^{7}$ American Academy on Pediatric Dentistry Clinical Affairs Committee; American Academy on Pediatric Dentistry Council on Clinical Affairs: Guideline on antibiotic prophylaxis for dental patients at risk for infection. Pediatr Dent 2008-2009;30:215-218

${ }^{8}$ American Academy of Pediatric Dentistry. Council on Clinical Affairs, Committee on the Adolescent: Guideline on oral health care for the pregnant adolescent. Pediatr Dent 2012;34:153-159

${ }^{9}$ Felton D, Cooper L, Duqum I, et al: Evidence-based guidelines for the care and maintenance of complete dentures: a publication of the American College of Prosthodontists. J Prosthodont 2011;20 Suppl 1:S1-S12

Journal of Prosthodontics, Vol 25, No. S1 (January 2016): pg. 532-540. DOI. This article is (C Wiley and permission has been granted for this version to appear in e-Publications@Marquette. Wiley does not grant permission for this article to be further copied/distributed or hosted elsewhere without the express permission from Wiley. 
NOT THE PUBLISHED VERSION; this is the author's final, peer-reviewed manuscript. The published version may be accessed by following the link in the citation at the bottom of the page.

${ }^{10}$ Ruggiero SL, Dodson TB, Fantasia J, et al: American Association of Oral and Maxillofacial Surgeons position paper on medication-related osteonecrosis of the jaw-2014 update. J Oral Maxillofac Surg $2014 ; 72: 1938-1956$

${ }^{11}$ National Guideline Clearing House. Agency for Healthcare Research and Quality, US Department of Health and Human Services. Available at: http://www.guideline.gov/index.aspx. Accessed on November 5, 2015

${ }^{12}$ Bidra AS: Evidence-based prosthodontics: fundamental considerations, limitations and guidelines. Dent Clin North Am 2014;58:1-17

${ }^{13}$ Bidra AS, Daubert DM, Garcia LT, et al: A systematic review of recall regimen and maintenance regimen of patients with dental restorations-Part 1: tooth-borne restorations. J Prosthodont 2016;25:S2-S15.

${ }^{14}$ Bidra AS, Daubert DM, Garcia LT, et al: A systematic review of recall regimen and maintenance regimen of patients with dental restorations-Part 2: implant-borne restorations. J Prosthodont 2016;25:S16-S31.

${ }^{15}$ Ercalik-Yalcinkaya S, Ozcan M: Association between oral mucosal lesions and hygiene habits in a population of removable prosthesis wearers. $J$ Prosthodont 2015;24:271-278

${ }^{16}$ Morino $\mathrm{T}$, Ookawa $\mathrm{K}$, Haruta $\mathrm{N}$, et al: Effects of professional oral health care on elderly: randomized trial. Int J Dent Hyg 2014;12:291-297

${ }^{17}$ Ekstrand $\mathrm{KR}$, Poulsen $\mathrm{JE}$, Hede $\mathrm{B}$, et al: $\mathrm{A}$ randomized clinical trial of the anti-caries efficacy of 5,000 compared to $1,450 \mathrm{ppm}$ fluoridated toothpaste on root caries lesions in elderly disabled nursing home residents. Caries Res 2013;47:391-398

${ }^{18}$ Fardal $\varnothing$, Grytten J: A comparison of teeth and implants during maintenance therapy in terms of the number of disease-free years and costs-an in vivo internal control study. J Clin Periodontol 2013;40:645-651

${ }^{19}$ De Visschere L, Schols J, van der Putten GJ, et al: Effect evaluation of a supervised versus non-supervised implementation of an oral health care guideline in nursing homes: a cluster randomised controlled clinical trial. Gerodontology 2012;29:e96-e106

${ }^{20}$ López-Jornet $\mathrm{P}$, Plana-Ramon $\mathrm{E}$, Leston JS, et al: Short-term side effects of $0.2 \%$ alcohol-free chlorhexidine mouthrinse in geriatric patients: a randomized, double-blind, placebo-controlled study. Gerodontology 2012;29:292-298

${ }^{21}$ van der Putten GJ, Mulder J, de Baat C, et al: Effectiveness of supervised implementation of an oral health care guideline in care homes; a single-blinded cluster randomized controlled trial. Clin Oral Investig 2013;17:1143-1153

Journal of Prosthodontics, Vol 25, No. S1 (January 2016): pg. 532-540. DOI. This article is (C Wiley and permission has been granted for this version to appear in e-Publications@Marquette. Wiley does not grant permission for this article to be further copied/distributed or hosted elsewhere without the express permission from Wiley. 
NOT THE PUBLISHED VERSION; this is the author's final, peer-reviewed manuscript. The published version may be accessed by following the link in the citation at the bottom of the page.

${ }^{22}$ Wolfart S, Weyer N, Kern M: Patient attendance in a recall program after prosthodontic rehabilitation: a 5-year follow-up. Int J Prosthodont 2012;25:491-496

${ }^{23}$ Zenthöfer $A$, Dieke $R$, Dieke A, et al: Improving oral hygiene in the longterm care of the elderly-a RCT. Community Dent Oral Epidemiol 2013;41:261-268

${ }^{24}$ Ababnaeh KT, Al-Omari M, Alawneh TN: The effect of dental restoration type and material on periodontal health. Oral Health Prev Dent 2011;9:395403

${ }^{25}$ Nassar CA, Serraglio AP, Balotin A, et al: Effect of maintenance therapy with or without the use of chlorhexidine in teeth restored with composite resin in patients with diabetes mellitus. Gen Dent 2011;59:e149-e152

${ }^{26}$ Ikai $\mathrm{H}$, Kanno $\mathrm{T}$, Kimura $\mathrm{K}$, et al: A retrospective study of fixed dental prostheses without regular maintenance. J Prosthodont Res 2010;54:173-178

${ }^{27}$ Ortolan SM, Viskić J, Stefancić S, et al: Oral hygiene and gingival health in patients with fixed prosthodontic appliances-a 12-month follow-up. Coll Antropol 2012;36:213-220

${ }^{28}$ Vered $Y$, Zini A, Mann J, et al: Comparison of a dentifrice containing $0.243 \%$ sodium fluoride, $0.3 \%$ triclosan, and $2.0 \%$ copolymer in a silica base, and a dentifrice containing $0.243 \%$ sodium fluoride in a silica base: a three-year clinical trial of root caries and dental crowns among adults. J Clin Dent 2009;20:62-65

${ }^{29}$ Ribeiro DG, Pavarina AC, Giampaolo ET, et al: Effect of oral hygiene education and motivation on removable partial denture wearers: longitudinal study. Gerodontology 2009;26:150-156

${ }^{30}$ Zoellner A, Heuermann M, Weber HP, et al: Secondary caries in crowned teeth: correlation of clinical and radiographic findings. J Prosthet Dent 2002;88:314-319

${ }^{31}$ Magnuson B, Harsono M, Stark PC, et al: Comparison of the effect of two interdental cleaning devices around implants on the reduction of bleeding: a 30-day randomized clinical trial. Compend Contin Educ Dent 2013;34 Spec No 8:2-7

${ }^{32}$ Morawiec T, Dziedzic A, Niedzielska I, et al: The biological activity of propolis-containing toothpaste on oral health environment in patients who underwent implant-supported prosthodontic rehabilitation. Evid Based Complement Alternat Med 2013;2013:704947

${ }^{33}$ Mussano F, Rovasio S, Schierano G, et al: The effect of glycine-powder airflow and hand instrumentation on peri-implant soft tissues: a splitmouth pilot study. Int J Prosthodont 2013;26:42-44

${ }^{34}$ Swierkot $K$, Brusius M, Leismann D, et al: Manual versus sonic-powered toothbrushing for plaque reduction in patients with dental implants: an

Journal of Prosthodontics, Vol 25, No. S1 (January 2016): pg. 532-540. DOI. This article is (c) Wiley and permission has been granted for this version to appear in e-Publications@Marquette. Wiley does not grant permission for this article to be further copied/distributed or hosted elsewhere without the express permission from Wiley. 
NOT THE PUBLISHED VERSION; this is the author's final, peer-reviewed manuscript. The published version may be accessed by following the link in the citation at the bottom of the page.

explanatory randomised controlled trial. Eur J Oral Implantol 2013;6:133-144

${ }^{35}$ Zou $D$, Wu $Y$, Huang $W$, et al: A 3-year prospective clinical study of telescopic crown, bar, and locator attachments for removable four implant-supported maxillary overdentures. Int J Prosthodont 2013;26:566-573

${ }^{36}$ De Siena F, Francetti L, Corbella S, et al: Topical application of $1 \%$ chlorhexidine gel versus $0.2 \%$ mouthwash in the treatment of periimplant mucositis. An observational study. Int J Dent Hyg 2013;11:4147

${ }^{37}$ Chongcharoen N, Lulic M, Lang NP: Effectiveness of different interdental brushes on cleaning the interproximal surfaces of teeth and implants: a randomized controlled, double-blind cross-over study. Clin Oral Implants Res 2012;23:635-640

${ }^{38}$ Costa FO, Takenaka-Martinez S, Cota LO, et al: Peri-implant disease in subjects with and without preventive maintenance: a 5-year follow-up. J Clin Periodontol 2012;39:173-181

${ }^{39}$ Fischer K, Stenberg T: Prospective 10-year cohort study based on a randomized, controlled trial (RCT) on implant-supported full-arch maxillary prostheses. Part II: prosthetic outcomes and maintenance. Clin Implant Dent Related Res 2013;15:498-508

${ }^{40}$ Katsoulis J, Brunner A, Mericske-Stern R: Maintenance of implant-supported maxillary prostheses: a 2-year controlled clinical trial. Int J Oral Maxillofac Implants 2011;26:648-656

${ }^{41}$ Akça K, Cehreli MC, Uysal S: Marginal bone loss and prosthetic maintenance of bar-retained implant-supported overdentures: a prospective study. Int J Oral Maxillofac Implants 2010;25:137-145

${ }^{42}$ Corbella S, Del Fabbro M, Taschieri S, et al: Clinical evaluation of an implant maintenance protocol for the prevention of peri-implant diseases in patients treated with immediately loaded full-arch rehabilitations. Int J Dent Hyg 2011;9:216-222

${ }^{43}$ Rentsch-Kollar A, Huber S, Mericske-Stern R: Mandibular implant overdentures followed for over 10 years: patient compliance and prosthetic maintenance. Int J Prosthodont 2010;23:91-98

${ }^{44}$ Sreenivasan $\mathrm{PK}$, Vered $\mathrm{Y}$, Zini A, et al: A 6-month study of the effects of $0.3 \%$ triclosan/copolymer dentifrice on dental implants. J Clin Periodontol 2011;38:33-42

${ }^{45}$ Thöne-Mühling M, Swierkot K, Nonnenmacher $C$, et al: Comparison of two full-mouth approaches in the treatment of peri-implant mucositis: a pilot study. Clin Oral Implants Res 2010;21:504-512

${ }^{46}$ Kleis WK, Kämmerer PW, Hartmann S, et al: A comparison of three different attachment systems for mandibular two-implant overdentures: oneyear report. Clin Implant Dent Relat Res 2010;12:209-218

Journal of Prosthodontics, Vol 25, No. S1 (January 2016): pg. 532-540. DOI. This article is (C) Wiley and permission has been granted for this version to appear in e-Publications@Marquette. Wiley does not grant permission for this article to be further copied/distributed or hosted elsewhere without the express permission from Wiley. 
NOT THE PUBLISHED VERSION; this is the author's final, peer-reviewed manuscript. The published version may be accessed by following the link in the citation at the bottom of the page.

${ }^{47}$ Paolantonio M, Perinetti G, D'Ercole S, et al: Internal decontamination of dental implants: an in vivo randomized microbiologic 6-month trial on the effects of a chlorhexidine gel. J Periodontol 2008;79:1419-1425

${ }^{48}$ Ramberg $P$, Lindhe J, Botticelli $D$, et al: The effect of a triclosan dentifrice on mucositis in subjects with dental implants: a six-month clinical study. $J$ Clin Dent 2009;20:103-107

${ }^{49}$ Rasperini G, Pellegrini G, Cortella A, et al: The safety and acceptability of an electric toothbrush on peri-implant mucosa in patients with oral implants in aesthetic areas: a prospective cohort study. Eur J Oral Implantol 2008;1:221-228

${ }^{50}$ Vandekerckhove B, Quirynen M, Warren PR, et al: The safety and efficacy of a powered toothbrush on soft tissues in patients with implantsupported fixed prostheses. Clin Oral Investig 2004;8:206-210

${ }^{51}$ Guyatt G, Akl EA, Hirsh J, et al: The vexing problem of guidelines and conflict of interest: a potential solution. Ann Intern Med 2010;152:738-741

${ }^{52}$ Guyatt GH, Schünemann HJ, Djulbegovic B, et al: Guideline panels should not GRADE good practice statements. J Clin Epidemiol 2015;68:597600

${ }^{53}$ Atkins $D$, Best $D$, Briss $P A$, et al: Grading quality of evidence and strength of recommendations. Br Med J 2004;328:1490

${ }^{54}$ Ebell $\mathrm{MH}$, Siwek J, Weiss BD, et al: Strength of recommendation taxonomy (SORT): a patient-centered approach to grading evidence in the medical literature. Am Fam Physician 2004;69:548-556

Journal of Prosthodontics, Vol 25, No. S1 (January 2016): pg. 532-540. DOI. This article is (C) Wiley and permission has been granted for this version to appear in e-Publications@Marquette. Wiley does not grant permission for this article to be further copied/distributed or hosted elsewhere without the express permission from Wiley. 